\title{
Microregional patterns of corporate philanthropy: the role of economic structure and regional determinants
}

\author{
Marek Halada ${ }^{1}$ - Jan Ženka ${ }^{1 \otimes}$ \\ ${ }^{1}$ Department of Human Geography and Regional Development, University of Ostrava, Czechia \\ 凶an.zenka@osu.cz
}

\begin{abstract}
We aim to describe and explain current differences in the rate of corporate philanthropy (CP) at microregional level. Primary research question is to what extent are microregional patterns of CP affected by determinants at firm and industry-level (firm size, industrial structure, profitability) and to what extent are they shaped by regional contextual factors. Measurement of CP was based on anonymized firm-level data provided by the Ministry of Finance, aggregated at the level of municipalities with extended powers (microregions). We employed a regression model to test the effects of population density, economic performance, specialization, dependence of manufacturing, firm size, traditional values and social capital. Surprisingly, we found no significant effects of firm size and industrial structure on regional CP. Firm's profitability was the most important predictor. We found also positive effects of population density and religiosity and negative relationship between $\mathrm{CP}$ and regional economic performance. Despite initial expectations higher rate of $\mathrm{CP}$ was not found in rural regions.
\end{abstract}

\section{Highlights for public administration, management and planning:}

- Donations are excessively concentrated to the capital city of Praha due to the headquarter effect.

- In majority of non-metropolitan regions the amount of local corporate gifts is very low, not allowing for a significant contribution to the development of local communities.

- Large manufacturing and mining companies are important donors, but there is no systematic relationship between their spatial distribution and rates of corporate philanthropy at microregional level.

- Firms in urban regions are on average more philanthropic than their rural counterparts.

\section{Introduction}

Except for several valuable contributions (e.g. Hurd et al. 1998; Card et al. 2010; Paarlberg \& Yoshioka 2016; Mohan \& Breeze 2016; Marshall et al. 2018; Ding et al. 2019), the geographies of corporate philanthropy (CP) have largely been neglected. Probably the most missing are empirical studies focusing on differences in the rate of $\mathrm{CP}$ at the city and regional level. Why are these studies so important and necessary? Recent economic globalisation has been favouring

\section{Keywords}

Corporate philanthropy,

Corporate social responsibility,

Regional differences,

Social capital,

Czechia

Received:

17 April 2019

Received in revised form: 7 May 2020

Accepted:

22 May 2020 
In this paper, we aim to describe and explain current regional differentiation of $\mathrm{CP}$ in Czechia: a small country characteristic by the sharp polarity in economic performance and wealth between the capital (Praha) and all other cities and regions (Ženka et al. 2014). Although there have been many studies focusing on various aspects of $\mathrm{CP}$ in this country, few authors deal with its spatial distribution. Fiala (2015) argued that large service firms donate primarily at the national level, while mining, manufacturing and energy firms prefer local or microregional level. Hána \& Černý (2017) or Černý (2018) documented spatially highly uneven distribution of donations provided by the Czech energetic company CEZ Group, concentrated in municipalities in the immediate proximity of its power plants. Fuchsová et al. (2018) found a relationship between regional economic performance and CP. Tetřevová et al. (2017) did not cope specifically with the geography, but proposed valuable case studies of CP in industries with high social/environmental externalities: chemicals, explosives, alcohol, tobacco, and gambling (see also Gurská \& Valová 2013 for evaluation of CP in mining).

While the above mentioned authors deal primarily with the regional/industry case studies or focus at the NUTS3 level (Fuchsová et al. 2018), we analyse CP at the level of the so-called municipalities with extended powers (further only „microregions"), administrative units roughly corresponding with nodal regions. This allows for a detailed analysis and testing of selected factors of $\mathrm{CP}$ at a (micro)regional level: population size and position in the settlement hierarchy, regional economic performance and structure, religiosity and social capital. We ask (i) to what extent are regional patterns of CP shaped by the compositional factors such as industrial/firm size structure or firm profitability that have no explicit spatial dimension and (ii) to what extent by purely regional contextual factors such as particular actors, institutions, policies or social capital (see Bekkers 2016 for a distinction between compositional and contextual factors) that are unique and not transferrable elsewhere. This paper should be considered as an introductory text providing some preliminary empirical results for a discussion. At this stage, we stick to the simple regression model and combine it with an interpretation based on our knowledge of the particular regional contexts. This is followed by ongoing construction of large firm-level dataset with reliable geocoded data that would be sufficient for description and testing of all relevant determinants of CP using a a multilevel regression model to distinguish between the compositional and contextual factors.
In the next section, we provide a brief review of selected determinants of $\mathrm{CP}$ at firm, industry and regional level. Section three proposes a contextualization of CP in Czechia from the institutional and legal point of view. In the fourth section, we describe data sources, indicators and methods. The fifth section summarizes the main empirical results, in the sixth section we discuss with approaches and findings of other authors. The seventh sention concludes and provides recommendations for further research.

\section{Determinants of corporate philanthropy}

In this paper we focus entirely on measurable economic aspect of CP: cash donation, tangible and intangible gifts. CP is primarily driven by companylevel factors, such as managerial strategies to increase firm visibility or improve its reputation (Arminen et al. 2018). Nevertheless, CP is also context-dependent (Jones 1999), because the firm behaviour and decision making is embedded within particular social structures, norms and institutions (Ioannou \& Serafeim, 2012: 835). Arminen et al. (2018: 4) argue that "two of the most important social structures that companies face are the country of operation and the industrial sector". For this paper, however, we focus on regional differences in $\mathrm{CP}$ rather than on the role of national contexts. Therefore, we classified determinants of CP into three groups: factors at the firm, industry and regional level (Table 1).

According to the findings of Useem (1988), the most important factor of $\mathrm{CP}$ at the firm level is firm size. There is probably a U-shaped relationship between the firm size and corporate profitability: very small firms and very large firms donate more than those medium-sized (Udayasankar 2008). While small firms aim to affect their immediate neighbourhood or to be visible within the local community, large firms give more to build a positive public image at (inter)national level (Amato \& Amato 2007). Their visibility increases pressure from the costumers and public to behave responsibly (Udayasankar 2008). Besides, large firms have better access to financial resources (Johnson \& Greenning 1999) and their administrative and management capacities allow them to be more socially responsive (Brammer \& Millington 2006).

As already suggested, CP is also associated with the economic performance of companies. Profitable firms are generally more likely to invest into corporate social responsibility (Arminen et al. 2018). Ac- 
Table 1 Selected factors affecting regional differences in the corporate philanthropy

\begin{tabular}{|c|c|c|}
\hline Factor & Mechanism & Sources \\
\hline \multicolumn{3}{|l|}{ Firm-level } \\
\hline Firm size & Large and small firms donate more than medium-sized firms. & $\begin{array}{l}\text { (Useem 1988); } \\
\text { (Johnson \& Greening 1999); } \\
\text { (Udaysankar 2008); } \\
\text { (Amato \& Amato 2007) }\end{array}$ \\
\hline Profitability & Current profitability of the firm is positively associated with $\mathrm{CP}$. & $\begin{array}{l}\text { (Jackson \& Apostolakou 2010); } \\
\text { (Ioannou \& Serafeim 2012); } \\
\text { (Arminen et al. 2018) }\end{array}$ \\
\hline Slack resources & $\begin{array}{l}\text { Slack resources resulting from the profitability } \\
\text { in the past increase CP. }\end{array}$ & $\begin{array}{l}\text { (Waddock \& Graves 1997); } \\
\text { (Melo 2012); } \\
\text { (Hartmann \& Uhlenbruck 2015) }\end{array}$ \\
\hline Risk & Financial risk lowers the rate of $\mathrm{CP}$. & (Arminen et al. 2018) \\
\hline $\begin{array}{l}\text { Non-local } \\
\text { ownership }\end{array}$ & $\begin{array}{l}\text { Non-local ownership has a direct negative effect on CP, } \\
\text { lowers social capital and also indirectly lowers } \mathrm{CP}^{1} \\
\text { Branch plants donate less than headquarters. }{ }^{1,2}\end{array}$ & $\begin{array}{l}{ }^{1} \text { (Paarlberg \& Yoshioka 2016); } \\
\text { (Card et al. 2010) }\end{array}$ \\
\hline Dispersion & $\begin{array}{l}\text { Geographically dispersed firms donate less than } \\
\text { concentrated firms. }^{2} \text { Firms with regionalized operations } \\
\text { donate more than globally integrated firms. }{ }^{3}\end{array}$ & $\begin{array}{l}{ }^{2} \text { (Shi et al. 2017); } \\
{ }^{3} \text { (Rugman \& Verbeke 2004); } \\
\text { (Fuchsová et al. 2018) }\end{array}$ \\
\hline \multicolumn{3}{|l|}{ Industry-level } \\
\hline Tangible products & $\begin{array}{l}\text { Manufacturing firms donate more than service firms. } \\
\text { Manufacturing firms give more at local/regional level, } \\
\text { service firms focus more at the national level. }\end{array}$ & (Hurd et al. 1998) \\
\hline $\begin{array}{l}\text { Customer } \\
\text { orientation }\end{array}$ & $\begin{array}{l}\text { Firms in industries with high intensity of contacts with } \\
\text { the customers give more than firms in industries with } \\
\text { less intensive contacts. }\end{array}$ & $\begin{array}{l}\text { (Useem 1988); } \\
\text { (Amato \& Amato 2007) }\end{array}$ \\
\hline Social externalities & $\begin{array}{l}\text { Firms in industries with visible social externalities donate } \\
\text { more to improve their image. }\end{array}$ & $\begin{array}{l}\text { (Brammer \& Millington 2005); } \\
\text { (Grogiou et al. 2015) }\end{array}$ \\
\hline $\begin{array}{l}\text { Environmental } \\
\text { externalities }\end{array}$ & $\begin{array}{l}\text { Firms in industries with visible environmental externalities } \\
\text { donate more to improve their image }{ }^{4} \text { OR they donate less, } \\
\text { because philanthropy in these industries has no } \\
\text { significant effect on corporate reputation. }{ }^{5}\end{array}$ & 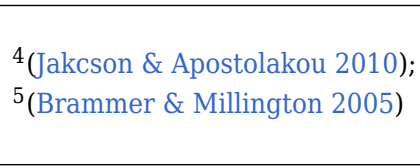 \\
\hline \multicolumn{3}{|l|}{ Regional level } \\
\hline $\begin{array}{l}\text { Economic } \\
\text { performance }\end{array}$ & $\begin{array}{l}\text { There is a positive relationship between regional economic } \\
\text { performance and CP. }\end{array}$ & $\begin{array}{l}\text { (Marshall et al. 2018); } \\
\text { (Fuchsová et al. 2018) }\end{array}$ \\
\hline $\begin{array}{l}\text { Position in the } \\
\text { urban hierarchy }\end{array}$ & $\begin{array}{l}\text { Charitable company trusts and foundations are concentrated } \\
\text { in metropolitan cores and their hinterlands. Firms with } \\
\text { headquarters located further from metropolitan cores donate } \\
\text { more than firms based in metropolitan cores }{ }^{6} \text {. }\end{array}$ & $\begin{array}{l}\text { (Hurd et al. 1998); } \\
{ }^{6} \text { (Boeprasert 2012) }\end{array}$ \\
\hline Rurality & $\begin{array}{l}\text { Firms in rural and sparsely populated regions may donate } \\
\text { more than firms in larger and denser urban regions. }\end{array}$ & (Bekkers 2008, 2016) \\
\hline $\begin{array}{l}\text { Economic } \\
\text { concentration }\end{array}$ & $\begin{array}{l}\text { Industrial specialization may affect negatively CP. } \\
\text { Concentrated firm size structure (dominance of a single large firm) } \\
\text { indirectly lowers local CP through adverse effects on social capital. }\end{array}$ & (Paarlberg Yoshioka 2016) \\
\hline Religiosity & Religiosity increases the rate of $\mathrm{CP}$. & $\begin{array}{l}\text { (Bekkers 2008, 2016); } \\
\text { (Wiepking et al. 2014) }\end{array}$ \\
\hline Social capital & $\begin{array}{l}\text { Social capital at the community level is positively } \\
\text { associated with CP. }\end{array}$ & (Jha Cox 2015) \\
\hline $\begin{array}{l}(\text { Old) industrial } \\
\text { regions }\end{array}$ & $\begin{array}{l}\text { Established manufacturing firms in (old) industrial regions } \\
\text { are tied to the local community more than geographically } \\
\text { mobile (service) firms and are characteristic by high CP. }\end{array}$ & $\begin{array}{l}\text { (Hurd 1998); } \\
\text { (Paarlberg \& Yoshioka 2016); } \\
\text { (Marshall et al. 2018) }\end{array}$ \\
\hline
\end{tabular}


cording to the slack resources hypothesis (Waddock \& Graves 1997; Melo 2012), availability of financial funds resulting from the good profitability in the past should increase the rate of CP. On the other hand, leverage, a proxy for a firm's riskiness, should affect CP negatively (Ho et al. 2012).

Apart from the regional-level factors (discussed below), geography affects $\mathrm{CP}$ also at the firm-level. Paarlberg \& Yoshioka (2016) argue that non-local ownership has a direct negative effect on $\mathrm{CP}$, considering ,...the ability of large multinational firms to relocate reduces their incentives to invest in local headquarters location than in their branch locations" (p. 342). Besides, the authors also discuss potential adverse effects of non-local ownership on local social capital that could indirectly lower CP. Geographically dispersed firms (especially those in small communities) donate generally less than local firms (Shi et al. 2017), because local firms are more dependent on social interaction with local stakeholders and on the quality of the local business environment. Presence of corporate headquarters increases local CP (Mohan \& Breeze 2016). Finally, firms with regionalized operations donate more at regional level than globally integrated firms (Rugman \& Verbeke 2004; Fuchsová et al. 2018).

Probably the most important factor affecting interindustry differences in $\mathrm{CP}$ is visibility of that industry for the stakeholders. The more visible are the activities of companies in an industry, the higher $\mathrm{CP}$ can be expected. Three basic variables that are positively related to industry visibility may be distinguished: tangibility, consumer orientation and externalities.

Manufacturing firms producing tangible products are generally more visible and donate more than service firms (Hurd et al. 1998). Firms in industries that are customer-oriented and focus on final products give more than firms in basic and intermediate industries (Useem 1988; Amato \& Amato 2007). For example, car producers are more visible and should donate more than suppliers of automotive components. Perhaps more importantly, firms in industries with significant negative social externalities are expected to donate more to improve their reputation. Typical examples are alcohol and tobacco products or gambling, but also some other stigmatized industries such as nuclear energy (see Hána \& Černý 2017, documenting how the Czech energetic company CEZ Group improves its image through donations in municipalities proximate to its nuclear power plant), pharmacy or some manufacturing industries characteristic by aggressive offshoring/outsourcing strategies (Jha \& Cox 2015). According to some authors, firms in indus- tries with visible environmental externalities (such as mining, energy, metallurgy, coke and refined petroleum, chemicals, construction) donate more to improve their image (Jackson \& Apostolakou 2010), while other authors argue that they donate less because philanthropy in these industries has no significant effect on corporate reputation (Brammer \& Millington 2005).

Due to their complexity and contextual nature, regional factors are significantly less explored than their firm and industry-level counterparts. Hurd et al. (1998) documented spatially highly uneven distribution of charitable trusts and foundations, concentrated into the largest metropolitan regions. CP thus follows wider processes of spatial centralisation and concentration in the economy. Nevertheless, firms with headquarters located outside metropolitan regions donate relatively more than firms based in metropolitan cores and their hinterlands to increase their transparency (e.g. for urban-based investors and financial institutions), see Boeprasert (2012).

Charitable giving is more likely to be successful in prospering regions with a dense network of donors and charitable organisation, some authors suggest a positive relationship between regional economic performance and CP (Wolpert 1995; Marshall et al. 2018; Fuchsová et al. 2018). Mill (1848) argued that there is a (spatial) mismatch between the distribution of charitable resources and social needs (see also Mohan \& Breeze 2016 for testing). Nevertheless, established manufacturing firms in (old) industrial regions have the strongest tradition of local philanthropy (Hurd et al. 1998) and are tied to their local communities more tightly than geographically mobile service firms in economically well-performing metropolitan regions. Paarlberg \& Yoshioka (2016) also argue that manufacturing firms may stimulate the development of social capital and contribute to higher $\mathrm{CP}$ also indirectly (while not proven by the test). While the rate of CP can be high also in economically lagging or declining regions, it is necessary to consider that „...the geographically embedded and personally driven nature of philanthropic motivations and impacts, and indicated that the positive outcomes of corporate philanthropy are difficult to sustain in disadvantaged regions where fragilities in the local economy and shifts in corporate strategy undermine charitable giving" (Marshall et al. 2018: 267).

Regional patterns of CP are also shaped by social and cultural factors, grouped around the so-called community explanation (Bekkers \& Schuyt 2008). According to this approach, variation in $\mathrm{CP}$ can be partly explained by intangible factors at the com- 


\section{Sciendo}

munity level. Probably the most important (apart from an ethnicity that is beyond the scope of this paper) is religiosity and social capital, the latter understood as social norms and networks that facilitate collective action (Woolcock 2001) through trust, reciprocity and other values. Regions with high level of religiosity may have higher levels of philanthropy (Ding et al. 2019), because not only individual religiosity but also religious communities create and reproduce social norms encouraging CP (Bekkers 2016: 29). Firms headquartered in high social capital regions are more likely to develop altruistic corporate culture and engage in $\mathrm{CP}$, especially when their suppliers, workers, lenders, and customers are located in their vicinity (Jha \& Cox 2015: 255). Communities are more closeknit in rural and lower population density regions, therefore, a negative relationship between population density and CP can be expected (Bekkers 2016: 30). As Paarlberg \& Yoshioka (2016) suggest, concentrated industrial and firm size structure (dominance of a single firm) may hamper local social capital and negatively affect $\mathrm{CP}$.

\section{Corporate philanthropy in Czechia: context}

In this section, we provide a brief characteristic of Czech institutions, legal framework and regional differences in selected factors of CP. Starting at a national level, Czechia is a small unitary state (78 $864 \mathrm{~km} 2,10.7$ mil. inhabitants in 2020) with three metropolitan cores: Praha, Brno, Ostrava (Fig. 1). The economic system is specific: Czechia and other Central European countries can be marked as "dependent market economies" (Nölke \& Vliegenthart 2009: 672), characteristic by the dominant position of large transnational corporations, dependence on foreign capital and decisions, major firms being mostly in the position of suppliers to Western European markets. Therefore, the spatial distribution of large foreign-owned companies and their headquarters is likely to affect CP significantly. Philanthropy of Czech households and companies is not significantly different from the situation in other European countries (Table 2). The most important donor in Czechia is a public

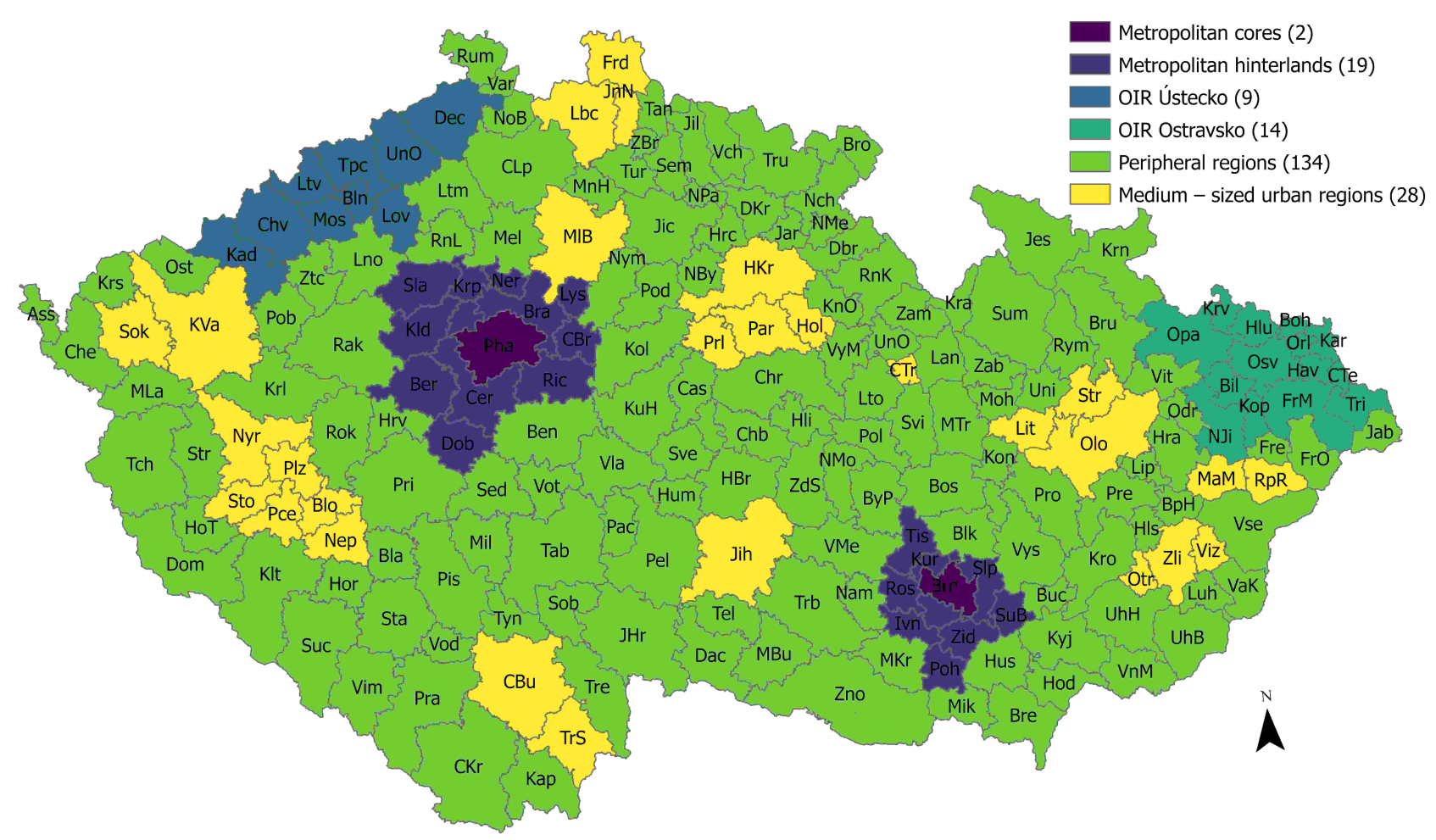

Fig. 1 Typology of regions in Czechia. Source: Ženka et al. (2019: 2294); Notes: Pha=Praha; Brn=Brno; Osv=Ostrava; $\mathrm{MlB}=$ Mladá Boleslav; Mos=Most; $\mathrm{Chv=Chomutov;} \mathrm{Dec=Děčín;} \mathrm{Vys=Vyškov;} \mathrm{Otr=Otrokovice;}$ Vot $=$ Votice 
sector, followed by households, leaving companies in the third place.

If we turn to the regional differentiation of $\mathrm{CP}$ determinants, probably the most important feature of Czechia (and all Central European countries) is sharp and increasing polarity in economic performance between the capital cities and all other regions (Petrakos 2001; Hampl 2007; Ženka et al. 2014). Superdominant position of the capital city of Praha results from the concentration of state administration bodies, highly skilled labour, universities and academia, corporate headquarters, financial sector and also foreign capital and investment due to their gateway function (Dostál 2008). Therefore, the capital will probably concentrate a large share of the total CP amount.

While metropolitan cores are dominated by services (Ženka et al. 2017a), manufacturing is the biggest employer in almost all non-metropolitan and rural regions (Ženka \& Wellisch 2020). Almost one-third of Czech non-metropolitan regions is heavily dependent on automotive or supplying industries (Ženka 2019), 14\% are regions dominated by foreignowned branch plants and 9\% by a large domestic manufacturing company (Ženka et al. 2017b). There are two major old industrial regions, Ústecký and Moravskoslezský region (Koutský 2011), characteristic by a concentration of industries with negative environmental externalities, such as coal mining, the refinery of petroleum products, energy, metallurgy or basic chemicals. Presence of large manufacturing firms in industries with visible negative environmental impact may increase the rate of CP. Czechia is a highly ethnically homogeneous country, so we do not expect significant effects of ethnicity on CP. Religiosity is generally low, but there is a clear urban-rural and west-east gradient, partly valid also for the differentiation of social capital. Rural regions in south-eastern part of the country are the most traditional and religious, while the largest cities and the north-western borderland represent the second extreme (Pileček \& Jančák 2010; Kůsová 2013).

\section{Data and methods}

We draw on an anonymized firm-level database (2016) of tax returns provided by the Financial Administration (MF 2016) and databases administrated by the Ministry of Finance (Administrative Register of Economic Subjects: ARES 2016) and the Czech Statistical Office (Register of economic subjects: RES 2016) - see Table 3. Data that were originally aggregated for the districts of financial offices were transformed and reaggregated for municipalities with extended powers (microregions): administrative units roughly corresponding to nodal regions. Data for economic subjects that could not be assigned to particular microregion were split proportionally between all microregions in the particular NUTS3 region $(1.1 \%$ of subjects from the national level was distributed between NUTS3 regions; then on average $5.7 \%$ of total turnover was distributed from NUTS3 to microregional level). We excluded subjects in public sector (47 thous. out of 435 thous. subjects) and subjects in gambling and betting activities (NACE 92). The former do not generally make profit that could be donated, the latter are obliged to donate by the law. The total amount of gifts, the share of gifts in turnover

Table 2 Donations in selected European countries (2013) in mil. EUR

\begin{tabular}{|c|c|c|c|c|c|c|c|}
\hline Country & $\begin{array}{l}\text { Households } \\
\text { (mil. CZK) }\end{array}$ & $\begin{array}{l}\text { Firms } \\
\text { (mil. CZK) }\end{array}$ & $\begin{array}{l}\text { Households }{ }^{1} \\
(\%)\end{array}$ & $\begin{array}{l}\text { Firms }{ }^{1} \\
(\%)\end{array}$ & $\begin{array}{l}\text { Total gifts }^{2} \\
\text { per capita } \\
(\mathrm{CZK})\end{array}$ & $\begin{array}{l}\text { Share of } \\
\text { gifts } \\
\text { in GDP } \\
(\%)\end{array}$ & $\begin{array}{l}\text { Share of } \\
\text { corporate } \\
\text { gifts in GDP } \\
(\%)\end{array}$ \\
\hline Austria & 9734 & 12655 & 37.9 & 49.3 & 3058 & 0.26 & 0.14 \\
\hline Belgium & 10870 & 10221 & 43.7 & 41.1 & 2241 & 0.2 & 0.1 \\
\hline Czechia & 11005 & 4245 & 68.1 & 26.3 & 1540 & 0.36 & 0.1 \\
\hline France & 91936 & 75712 & 40.3 & 33.2 & 3463 & 0.29 & 0.13 \\
\hline Germany & 170352 & 303443 & 27.3 & 48.6 & 7744 & 0.62 & 0.4 \\
\hline Hungary & 2461 & 4840 & 20.3 & 39.9 & 1239 & 0.27 & 0.18 \\
\hline Italy & 194688 & 27040 & 79.3 & 11 & 4080 & 0.51 & 0.06 \\
\hline Slovakia & 2596 & 1704 & 53.3 & 35 & 901 & 0.22 & 0.09 \\
\hline Spain & 27419 & 9275 & 27.6 & 9.3 & 2135 & 0.13 & 0.03 \\
\hline United Kingdom & 442915 & 74360 & 64.7 & 10.9 & 10677 & 0.94 & 0.13 \\
\hline
\end{tabular}


and profitability were calculated from the data provided by the Financial Administration. Calculation of the share of gifts in turnover used this formula:

$$
\text { GIFTS }_{\text {share }}=\frac{\text { sum of gifts }}{\text { net turnover }} \cdot 1000000
$$

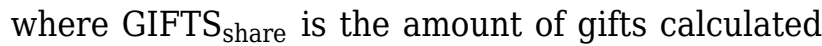
per 1 mil. CZK of, the sum of gifts is the total amount of all gifts in the microregion and net turnover is a sum of turnovers of all firms in the microregion. Definition of gift on Czech tax legislation (Income Tax Act 586/1992 Coll., the amendment from 2014) as a voluntary donation without fulfilling any legal obligation that would result from a contract. Indicators of economic performance, specialization and firm size structure were based on the Register of economic subjects in selected production industries provided by the Czech Statistical Office. This database covers only firms in agriculture, forestry and fishing (NACE 1-3), manufacturing (10-33), construction (41-43) and selected business services (49-82): no better database of economic indicators at a microregional level is available.

To analyse the effects of selected determinants, we employed a classic OLS regression model with the share of $\mathrm{CP}$ in turnover at a microregional level as the dependent variable. Besides, we also ran the second regression model testing the effect of population size on the total amount of gifts. Explanatory variables included to the models are listed below (Table 3). Calculation of Moran's I proved no significant spatial autocorrelation of selected variables, so the addition of the spatial regression models was not necessary

Due to unavailability of detailed economic data at a microregional level, we tested neither the share of industries with significant social and environmental externalities nor specialization in consumeroriented industries. Although we were unable to get precise numbers, the basic spatial distribution of these industries is well-known and was taken into consideration in the discussion of empirical results. Traditional values and religiosity were measured by the share of Christian and Democratic Union - Czechoslovak People's Party (KDU-ČSL) in 2014 municipal elections: this party has a strong position in rural municipalities and small towns with higher levels of religiosity (Kostelecký et al. 2014) and continuity in historical development.

\section{Results}

Let us start with several basic descriptive statistics of CP and its localisation in Czechia (Table 4;Fig. 2). The most pronounced feature of $\mathrm{CP}$ is an extremely high spatial concentration into the largest metropolitan core. In 2016 the capital city of Praha accounted for $46.7 \%$ of total gifts in the country. Correspondingly, in 2016 Praha concentrated half of total turnover, one-third of profits and $41 \%$ of the total tax base.

Apart from Praha, the largest amount of CP were found in other metropolitan cores (the second is Brno with 5.5\% share), regional capitals and nonmetropolitan regions with large manufacturing (or mining) firms, such as Mladá Boleslav, Most, Třinec or Otrokovice. Regional amounts of gifts range from 1.42 bil. CZK in Praha to 174 thous. CZK in peripheral region Votice (1 USD 24 CZK; 1 EUR 27 CZK). In almost half of all Czech microregions (93) amounts of donations were lower than 2.5 mil. CZK.

Table 3 Variables entering the regression models

\begin{tabular}{llll}
\hline Variable & Indicator & Period & Sources \\
\hline \multirow{3}{*}{ Total gifts } & & (MF (2016)); \\
& Total amount of gifts in CZK (dependent variable) & 2016 & ARES (2016); \\
Gifts in turnover & Share of gifts in turnover (\%) (dependent variable) & RES (2016) \\
Economic performance & Value added per capita & 2016 & MF (2016) \\
& Industrial specialization (Herfindahl-Hirschmann index & 2014 & CSO (2014a) \\
Specialization & at NACE rev. 2.0 calculated from employment) & 2014 & CSO (2014a) \\
Firm size & Herfindahl-Hirschmann index of the firm size (based on employment) & 2017 & CSO (2017) \\
Profitability & Return on sales: EBIT (profit) divided by total sales & 2016 & MF (2016) \\
Manufacturing & Share of manufacturing in total employment (\%) & 2014 & CSO (2014a) \\
Population density & Population per km ${ }^{2}$ & 2016 & CSO (2016) \\
Traditional values & Support for KDU-CSL in municipal elections & 2014 & CSO (2014b) \\
Social capital & Voter turnout in municipal elections & 2014 & CSO (2014b) \\
\hline
\end{tabular}




\section{S sciendo}

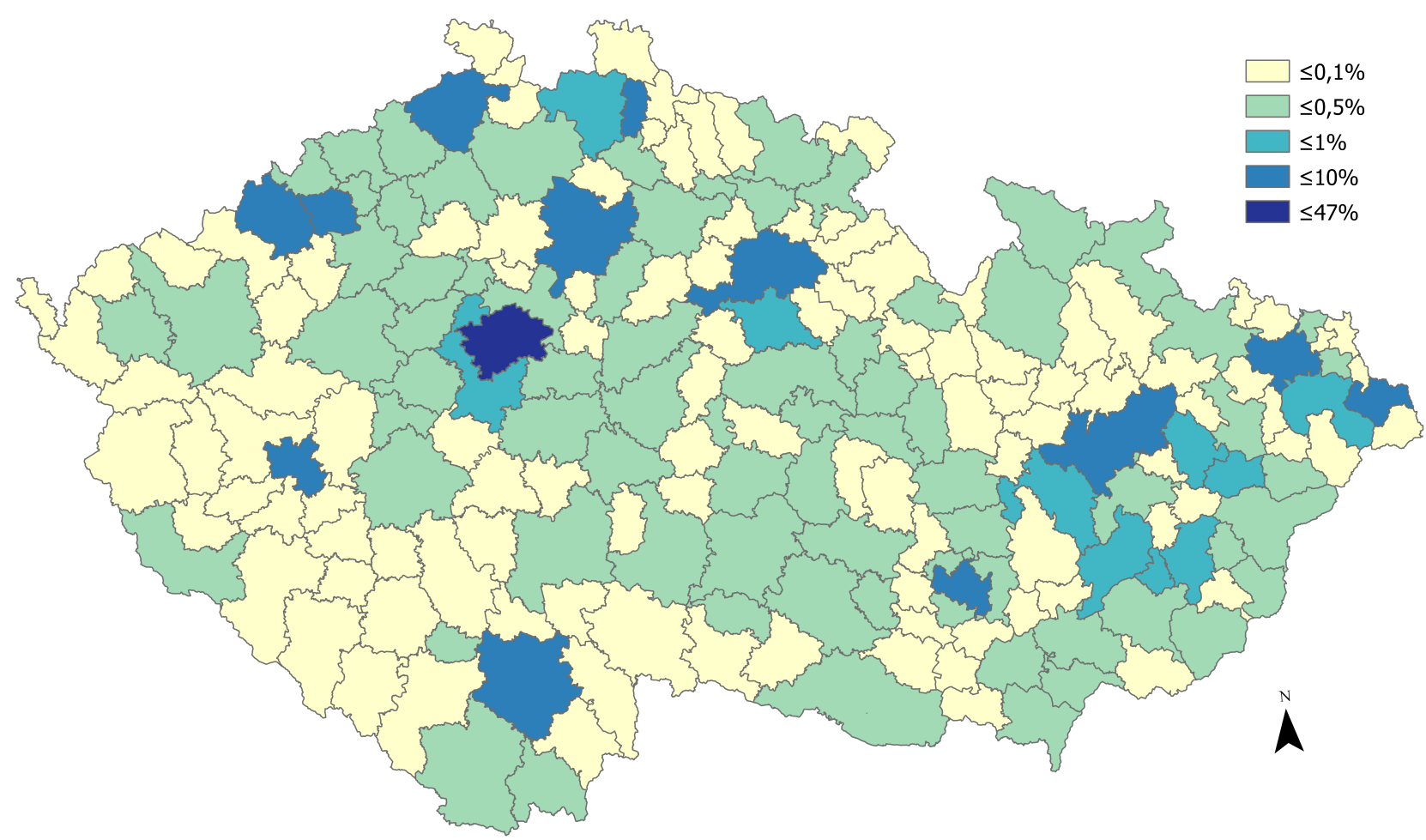

Fig. 2 Share of microregions in total amount of CP in Czechia (2016). Source: MF (2016)

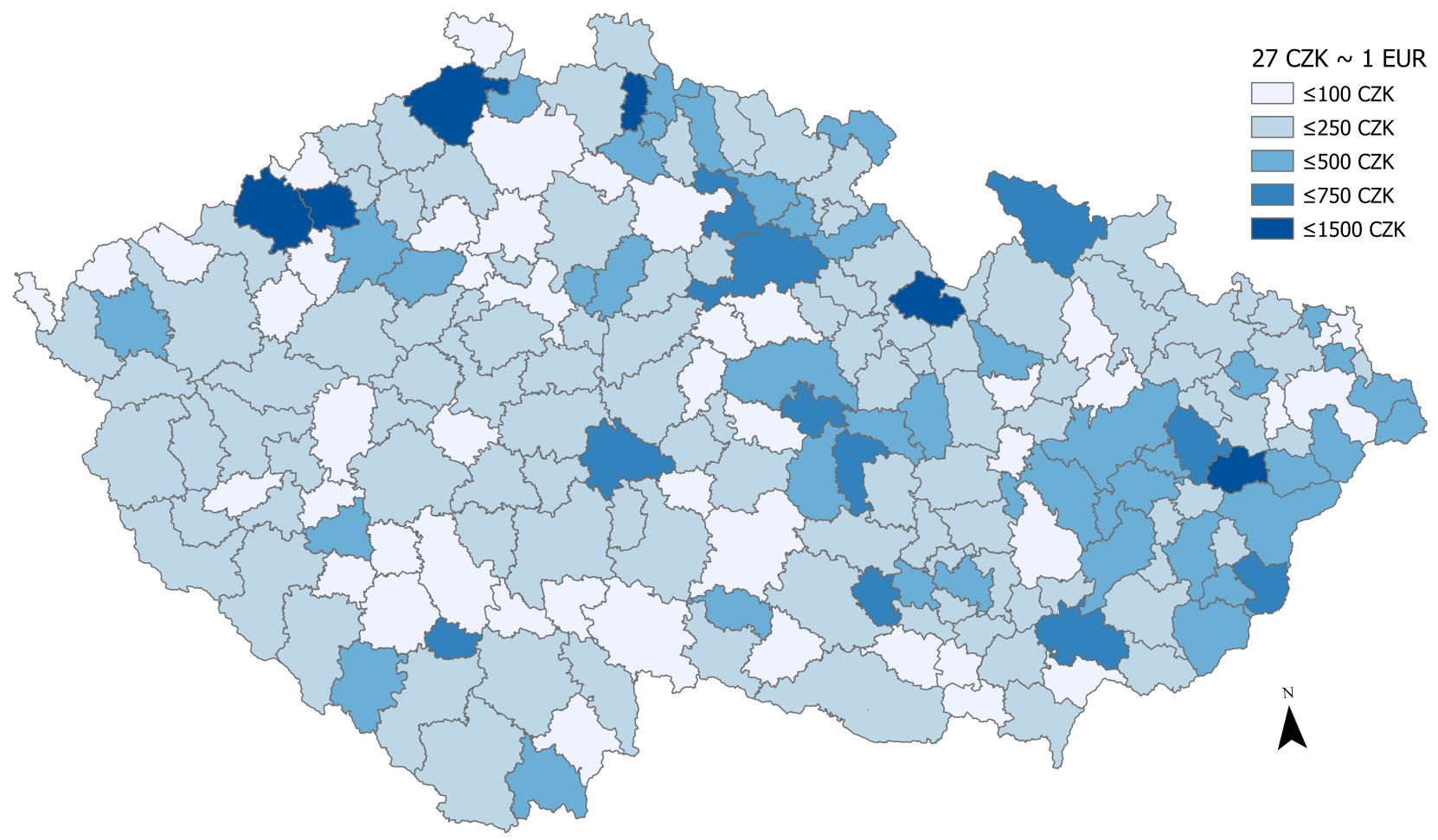

Fig. 3 Share of CP in turnover in 2016 (gifts in CZK per 1 mil. CZK of turnover). Source: MF (2016)

If we turn to the share of $\mathrm{CP}$ in turnover (Fig. 3), regional patterns change significantly. Higher relative $\mathrm{CP}$ is characteristic rather for small or medium- sized non-metropolitan regions, most of them heavily dominated by manufacturing industries. Mean share of $\mathrm{CP}$ in turnover is $0.02 \%$, ranging from 
Table 4 Corporate philanthropy at national level: descriptive statistics (2016)

\begin{tabular}{|c|c|c|c|c|}
\hline Number of subjects & Net turnover (bil. CZK) & Gifts amount (mil. CZK) & Number of donors & Gifts per 1 mil. CZK turnover (CZK) \\
\hline 366714 & 15117 & 3038 & 20465 & 200.97 \\
\hline
\end{tabular}

Source: MF (2016)

0.15\% (Most) to 0,0023\% (Vyškov). The share of CP in the tax base at the national level is $0.4 \%$. Firms in the most philanthropic microregion (Valašské Meziřičí) donated on average $1.7 \%$ of their tax base. While some neighbouring microregions share similar rates of $\mathrm{CP}$, overall regional picture is rather fragmented. High variability can be found not only at the national level, but also inside particular NUTS3 regions.

In the second part of the section, we introduce results of our regression models. We start with a simple OLS model testing the relationship between population size and the total amount of CP. Position in urban hierarchy measured by population size explained $63.5 \%$ of the variability in the amount of $\mathrm{CP}$ $(\mathrm{R}=0.797 ; \mathrm{B}=1.478 ; \mathrm{p}<0.001)$. Addition of other variables suprisingly did not increase significantly coefficient of determination, so we keep the model as simple as possible. The second model tested the effects of selected explanatory variables (Table 5), which in combination explained $20 \%$ of the share of CP in turnover. Surprisingly, industry and firm structure showed no significant relationships with the dependent variable. Although there are several microregions with large mining and manufacturing firms characteristic by high $\mathrm{CP}$ both in absolute and relative terms, there is no systematic relationship between concentrated firm structure and CP. Dependence on manufacturing did not increase the rates of $\mathrm{CP}$, nor did industrial specialization.
No significant effects were recorded also in case of social capital, represented by voter turnout in municipal elections. On the other hand, we found significant effects of population density, profitability, regional economic performance and religiosity/traditional values. Return on sales showed the strongest positive association with the share of $\mathrm{CP}$ in turnover, religiosity and population density were also positively related with the dependent variable. Regional economic performance, on the other hand, showed a relatively strong negative effect.

\section{Discussion}

Regression models in the previous section showed some results that may seem contradictory at first sight. While a firm's profitability was positively associated with the share of CP in turnover, the regional economic performance showed a negative effect. This contrasts with the argumentation of Mohan \& Breeze (2016), who found fewer charities in poorer areas. Apart from metropolitan cores, the highest economic performance is found in microregions with large (both domestic and foreignowned) companies or branch plants in technology or capital-intensive manufacturing industries (see also Ženka et al. 2015). Share of valueadded and profits in turnover in this kind of companies (car assemblers, miners) is generally low.

Table 5 Correlates of the share of CP in turnover (2016)

\begin{tabular}{|c|c|c|c|c|c|c|c|c|}
\hline \multicolumn{9}{|c|}{ Coefficients $^{a}$} \\
\hline \multicolumn{2}{|c|}{ Model } & \multicolumn{2}{|c|}{ Unstandardized Coefficients } & \multirow{2}{*}{$\begin{array}{c}\begin{array}{c}\text { Standardized } \\
\text { Coefficients }\end{array} \\
\text { Beta }\end{array}$} & \multirow[t]{2}{*}{$\mathrm{t}$} & \multirow[t]{2}{*}{ Sig. } & \multicolumn{2}{|c|}{ Collinearity Statistics } \\
\hline & & B & Std. Error & & & & Tolerance & VIF \\
\hline \multirow{9}{*}{1} & (Constant) & 1.444 & 1.338 & & 1.079 & 0.282 & & \\
\hline & Log_Economic performance & -0.328 & 0.117 & -0.21 & -2.808 & 0.005 & 0.728 & 1.374 \\
\hline & Log_Specialization & -0.101 & 0.138 & -0.063 & -0.731 & 0.466 & 0.552 & 1.812 \\
\hline & Log_Firm size & -0.08 & 0.267 & -0.024 & -0.299 & 0.765 & 0.626 & 1.596 \\
\hline & Log_Manufacturing & 0.149 & 0.248 & 0.046 & 0.601 & 0.548 & 0.684 & 1.461 \\
\hline & Log_Social capital & 0.097 & 0.531 & 0.014 & 0.183 & 0.855 & 0.67 & 1.492 \\
\hline & Log_Population density & 0.232 & 0.083 & 0.227 & 2.786 & 0.006 & 0.611 & 1.636 \\
\hline & Log_Traditional values & 0.208 & 0.082 & 0.172 & 2.545 & 0.012 & 0.883 & 1.132 \\
\hline & Log_Profitability & 0.719 & 0.132 & 0.354 & 5.466 & 0 & 0.966 & 1.035 \\
\hline
\end{tabular}

a Dependent Variable: Log_Gifts turnover

Source: CSO (2014a); CSO (2014̄b); CSO (2017); MF (2016) 
High profitability (return on sales), on the other hand, is found in several peripheral microregions specialized in labour-intensive manufacturing industries. While regional economic performance affects the share of CP in turnover negatively, it showed a positive effect on the total amount of gifts (see also Fuchsová et al. 2018 for the similar conclusion of their analysis aimed at NUT3 regions). The largest absolute amounts of gifts are - not surprisingly - found in economically wellperforming metropolitan cores, regional capitals and non-metropolitan regions with large manufacturing or mining companies.

While there is a positive correlation $(\mathrm{R}=0.367$; $\mathrm{p}<0.01$ ) between the voter turnout and support for KDU-CSL in municipal elections, only the latter variable as a proxy of religiosity and traditional value is positively associated with the share of $\mathrm{CP}$ in turnover. We confirmed findings of Ding et al. (2019) who analysed geographies of corporate social responsibility in the USA or Bekker (2016), focusing on regional patterns of individual philanthropy in the Netherlands. We failed to prove higher $\mathrm{CP}$ in high social capital regions that were suggested by Jha \& Cox (2015). However, more complex operationalization of social capital might uncover this relationship. Mechanisms through which social capital affects $\mathrm{CP}$ are not well understood yet, further qualitative inquiry is needed.

In contrast to our anticipation, $\mathrm{CP}$ is positively associated with population density. Denser urban regions are on average more philanthropic than sparsely populated rural areas. Therefore, we found support neither for Boeprasert's (2012) argument that rural firms are more socially responsible to increase their transparency nor for the community explanation (Bekkers 2016) that expects higher CP in small rural communities, where firms are highly visible, embedded and expected to donate locally. The latter finding does not necessarily falsify the community explanation: small communities certainly stimulate local $\mathrm{CP}$, but denser urban regions may show higher $\mathrm{CP}$ due to the presence of several large generous firms.

Probably the most important (while not always surprising) findings are related to the position in urban hierarchy, economic structure and profitability. Starting with the first, we found that population size is a key factor explaining the spatial distribution of the amount of CP in absolute terms (in line with Hurd et al. 1998). In 2016 the capital city of Praha concentrated almost one-half of the total amount of gifts. However, population size affects $\mathrm{CP}$ probably indirectly through the so-called headquarter effect (see Mohan \& Breeze 2016). Concentra- tion of corporate headquarters into the capital city increase $\mathrm{CP}$, because headquarters in metropolitan cores rather than branch plants in rural areas decide about the funding of philanthropic activities. While the strong effect of population size on the total amount of CP is expectable, there is only a weak association between population size and the share of $\mathrm{CP}$ in turnover $(\mathrm{R}=0.100 ; \mathrm{p}=0.154)$.

Despite initial expectations, no significant effects of industrial and firm size structure on CP were documented (in line with findings of Paarlberg \& Yoshioka 2016 from the USA). Regions characteristic by dependence on manufacturing, specialized and/or concentrated firm size structure were expected to show higher CP than their counterparts with the rather dispersed service-based economy. We certainly do not contest validity of the argument that very large (manufacturing) firms donate relatively more than those medium-sized (as suggested by Udayasankar 2008 or Amato \& Amato 2008), but at regional level, there are probably several factors (some of them still unexplored) that overshadow the effects of economic concentration. One of them was the profitability of companies: factor with a stronger positive effect on $\mathrm{CP}$ than any other explanatory variable (see Jakcson \& Apostolakou 2010 or Arminen et al. 2018 for support of this relationship).

\section{Conclusions}

In this paper, we aimed to describe and explain current regional differentiation of CP in Czechia. Our primary research question was if regional differences in $\mathrm{CP}$ are driven primarily by a firm and industry-level determinants (e.g. firm size and industrial structure, profitability), or if and to what extent regional contextual factors matter. While company profitability showed the strongest (positive) effect of all tested variables, other firmlevel and industry-level determinants were found statistically insignificant. This does not mean that we falsified hypotheses that firm size or industrial structure are related to CP. Rather, this shows that at the microregional level their effects were eclipsed by company profitability, overall regional economic performance (negative effect) and partly also by religiosity and traditional values that may positively stimulate $\mathrm{CP}$ in some rural regions. While the effect of social capital represented by the voter turnout in municipal elections was not proven, we argue that regional differences in CP cannot be explained only by firm and industry-level determinants: regional contexts are important. Besides, 
regional patterns of $\mathrm{CP}$ are also affected by nonfinancial types of profitability, such as volunteering or free provision of social services.

It is a question which findings from Czechia can be valid also for other countries and which of them are contextual. Highly uneven spatial distribution in the amount of $\mathrm{CP}$ and differentiated microregional patterns of $\mathrm{CP}$ are findings with more general relevance. Excessive concentration of $\mathrm{CP}$ to the capital city of Praha reflects its superdominant position in the urban hierarchy and also in the Czech economy. This finding is probably valid also for other smaller countries like Czechia that are characteristic by the concentration of economic outputs to their largest metropolitan cores. Headquarter effect seems to be the most relevant explanation of this kind of spatial pattern. Many firms headquartered in the capital city run their production operations in non-metropolitan regions, while donations even at a local level can be decided and executed in the capital. If we skip from the total amount of CP to the share of CP in turnover, firms in metropolitan cores are not more philanthropic than firms elsewhere, but positive relationship between population density and $\mathrm{CP}$ has been recorded. Last, even in Czechia as one of the least religious countries in the world, local religiosity and traditional values expressed indirectly in voting preferences affect microregional patterns of $\mathrm{CP}$. In more religious and culturally more heterogeneous countries stronger effects could be expected.

Nevertheless, many important questions remain unanswered and should be addressed in future research. These research questions can be streamlined in the three directions guiding the reseach agenda. Firstly, we need to evaluate trends in the spatial distribution of $\mathrm{CP}$ and differences at the microregional level with respect to two questions: (i) is there an increasing spatial concentration of gifts into the metropolitan cores or rather a dispersion?; (ii) Are the regional differences in the rate of $\mathrm{CP}$ rising or declining? Secondly, there is a space for studies using multilevel regression models that would be able to quantify the importance of firm-level, industry-level and regional contextual factors for the explanation of regional variations in the rate of CP. Finally, very few is known about the mechanisms through which social and cultural factors at the local level affect CP. Therefore, we call for more studies focusing on mutual relationships between local economic structure, social capital and culture and their effects on the rate of $\mathrm{CP}$.

\section{Acknowledgement}

This work was supported by the research project SGS17/PřF/2020 SMART cities and innovative approaches to the development of cities and regions. We thank to David Vogt for providing us datasets covering municipal election.

\section{References}

Amato LH, Amato CH (2007) The effects of firm size and industry on corporate giving. Journal of Business Ethics 72: 229-241.

ARES (2016) Administrative Register of Economic Subjects. Ministry of Finance. Praha.

Arminen H, Puumalainen K, Pätäri S, et al. (2018) Corporate social performance: Inter-industry and international differences. Journal of Cleaner Production 177: 426-437.

Bekkers R (2016) Regional differences in philanthropy. Routledge companion to philanthropy. Routledge, London.

Bekkers R, Schuyt T (2008) And who is your neighbor? explaining denominational differences in charitable giving and volunteering in the Netherlands. Review of Religous Research 50: 74-96.

Bekkers R, Veldhuizen I (2008) Geographical differences in blood donation and philanthropy in the netherlands - what role for social capital? Tijdschrift voor economische en sociale geografie 99: 483-496.

Bernard J, Kostelecký T, Šimon M (2014) Are there spatially contextual influences on voter behaviour even in a relatively nationalised party system? The case of Czechia. Geografie 119: 240-258. [in Czech]

Boeprasert A (2012) Does geographical proximity affect corporate social responsibility? Evidence from U.S. market. International Business Research 5: 138-147.

Brammer S, Millington A (2005) Corporate reputation and philanthropy: an empirical analysis. Journal of Business Ethics 61: 29-44.

Card D, Hallock KF, Moretti E (2010) The geography of giving: the effect of corporate headquarters on local charities. Journal of Public Economics 94: 222-234.

CSO (2014a) Annual register of economic subjects in selected production industries. Czech Statistical Office. Praha.

CSO (2014b) Public Database. Czech Statistical Office. Praha.

CSO (2016) Public Database. Czech Statistical Office. Praha.

CSO (2017) Public Database. Czech Statistical Office. Praha.

Černý, T. (2018) Spatial impact of ČEZ corporation social responsibility on development of municipalities. Master Thesis. Charles University. Praha. [in Czech]

Ding DK, Ferreira C, Wongchoti U (2019) The geography of CSR. International Review of Economics \& Finance 59: 265-288.

Dostál P (2008) “The post-communist capital city effects, transactional activities and regional development in the Czech Republic in the 1990s," In: Strubelt W., Gorzelak G. (Eds.), City and Region. Papers in Honour of Jiri Musil., Opladen. Budrich UniPress, 15-42. 


\section{sciendo}

Fiala, M. (2015) Corporate social responsibility in Czechia: spatial aspects and importance to regional development. Master Thesis. Charles University. Praha. [in Czech]

Fuchsová E, Laštovková J, Jánská M (2018) The influence of wealth on philanthropy: A cross-regional study. GeoScape 12: 104-113.

Grougiou V, Dedoulis E, Leventis S (2016) Corporate social responsibility reporting and organizational stigma: the case of "Sin" industries. Journal of Business Research 69: 905-914.

Gurská, S., Valová, A. (2013) Corporate social responsibility in mining industry. Acta Universitatis Agriculturae et Silviculturae Medelianae Brunensis LXI: 2163-2170. [in Czech]

Hampl M (2007) Regionální diferenciace současného socioekonomického vývoje v České Republice. Sociologicky Casopis 43 889-910.

Hána, D., Černý, T. (2017) Spatial Dimension of ČEZ Corporation's Financial Support to Municipalities Near the Dukovany Nuclear Plant. Naše společnost 2: 3-14. [in Czech]

Hartmann J, Uhlenbruck K (2015) National institutional antecedents to corporate environmental performance. Journal of World Business 50: 729-741.

Hoolwerf B, Schuyt T (2017) Giving in Europe Factsheet. Society 14-15.

Hurd H, Mason C, Pinch S (1998) The geography of corporatephilanthropy in the United Kingdom. Environment and Planning $\mathrm{C}$ : Government and Policy 16: 3-24.

Ioannou I, Serafeim G (2012) What drives corporate social performance? The role of nation-level institutions. Journal of International Business Studies 43: 834-864.

Jackson G, Apostolakou A (2010) Corporate Social Responsibility in Western Europe: An Institutional Mirror or Substitute? Journal of Business Ethics 94: 371-394.

Jha A, Cox J (2015) Corporate social responsibility and social capital. Journal of Banking \& Finance 60: 252-270.

Johnson RA, Greening DW (1999) The effects of corporate governance and institutional ownership types on corporate social performance. Academy of Management Journal 42: 564-576.

Jones MT (1999) The institutional determinants of social responsibility. Journal of Business Ethics 20: 163-179.

Koutský J (2011) Staré průmyslové regiony - vývojové tendence, možnosti rozvoje. PhD thesis

Kůsová T (2013) Volný čas a sociální kapitál: Prostorová diferenciace spolkové aktivity v česku. Geografie-Sbornik CGS 118: 372-391.

Marshall N, Dawley S, Pike A, et al. (2018) Geographies of corporate philanthropy: The Northern Rock Foundation. Environment and Planning A: Economy and Space 50: 266-287.

Melo T (2012) Slack-resources hypothesis: a critical analysis under a multidimensional approach to corporate social performance. Social Responsibility Journal 8: 257-269.

MF (2016) Financial Administration. Ministry of Finance. Praha, Czechia.

Mill JS (1848) Principles of political economy with some of their applications to social philosophy. London.

Mohan J, Breeze B (2016) The logic of charity: Great expectations in hard times, London, Palgrave Macmillan UK.

Nölke A, Vliegenthart A (2009) Enlarging the varieties of capitalism: the emergence of dependent market economies in East Central Europe. World Politics 61: 670-702.
Paarlberg LE, Yoshioka T (2016) The impact of local economic Structure on community philanthropy. Public Administration Review 76: 340-350.

Petrakos G (2001) Patterns of regional inequality in transition economies. European Planning Studies 9: 359-383.

Pileček J, Jančák V (2010) Je možné měřit sociální kapitál? Analýza územní diferenciace okresů Česka. Geografie-Sbornik CGS 78-95.

RES (2016) Register of economic subjects. Czech Statistical Office. Praha.

Rugman AM, Verbeke A (2004) A perspective on regional and global strategies of multinational enterprises. Journal of International Business Studies 35: 3-18.

Shi G, Sun J, Zhang L, et al. (2017) Corporate social responsibility and geographic dispersion. Journal of Accounting and Public Policy 36: 417-428.

Udayasankar K (2008) Corporate social responsibility and Firm Size. Journal of Business Ethics 83: 167-175.

Useem M (1988) Market and institutional factors in corporate contributions. California Management Review 30: 77-88.

Tetřevová, L., Vávra, J., Bednař́ková, M., Munzarová, S. Koštálová, J. (2017) Společenská odpovědnost firem společensky citlivých odvětví. Grada, Praha. [in Czech]

Waddock SA, Graves SB (1997) The corporate social performance-financial performance link. Strategic Management Journal 18: 303-319.

Wiepking P, Bekkers RHFP, Osili UO (2014) Examining the association of religious context with giving to non-profit organizations. European Sociological Review 30: 640-654.

Wolpert J (1995) Giving and region: generous and stingy communities. New Directions for Philanthropic Fundraising 1995: 11-30.

Woolcock M (2001) The place of social capital in understanding social and economic outcomes. Canadian Journal of Policy Research 2: 1-35.

Ženka J, Novotný J, Csank P (2014) Regional competitiveness in Central European Countries: in search of a useful conceptual framework. European Planning Studies 22: 164-183.

Ženka J, Novotný J, Slach O, et al. (2015) Industrial specialization and economic performance: A case of Czech microregions. Norsk Geografisk Tidsskrift - Norwegian Journal of Geography 69: $67-79$

Ženka J, Novotný J, Slach O, et al. (2017) Spatial distribution of knowledge-intensive business services in a small postcommunist economy. Journal of the Knowledge Economy 8: 385-406.

Ženka J, Slach O, Sopkuliak A (2017) Typologie českých nemetropolitních regionů z hlediska faktorů, mechanismů a aktérů regionálního rozvoje. Geografie 122: 281-309.

Ženka J, Slach O, Pavlík A (2019) Economic resilience of metropolitan, old industrial, and rural regions in two subsequent recessionary shocks. European Planning Studies 27: 2288-2311.

Ženka J, Wellisch S (2020) Sektorová struktura hospodářství I.: dominantní ekonomický sektor [mapa] [online]. Atlas rozvoje venkova Měŕítko 1:1 2500001 vyd Ostrava: Ostravská univerzita. 